\title{
KRAJSKÁ MĚSTA V MÉDIÍCH: KVANTITATIVNÍ A KVALITATIVNÍ ASPEKTY
}

\section{REGIONAL CAPITALS IN MEDIA: QUANTITATIVE AND QUALITATIVE ASPECTS}

\author{
DOC. ING. JAN SUCHÁČEK, PH.D. \\ Katedra regionální a environmentální ekonomiky $\mid$ Dep. of Regional and Environmental Economics \\ Ekonomická fakulta Faculty of Economics \\ Vysoká škola báňská-Technická univerzita Ostrava VŠB-Technical University of Ostrava \\ $\triangle$ Havlíčkovo nábřeži 38a, 70121 Ostrava, Czech Republic \\ E-mail: jan.suchacek@vsb.cz
}

\begin{abstract}
Anotace
Reference sdělovacích prostředků o jednotlivých typech území přispívaji k utváření mentálních map. Televizni zpravodajství se přitom vyznačuje nejen vysokým stupněm dopadu na publikum, ale podle srovnáni je také dostatečně reprezentativni. Cílem našeho článku je kvantitativni a kvalitativní analýza a interpretace př́spěvků o krajských městech v rámci celostátního televizního zpravodajství. Hodnocen zde je nejen počet přispěvků vztažených kjednotlivým krajským městům, ale také jejich obsahová skladba. Analýza ukázala, že se z kvantitativniho hlediska projevila u počtu přispěvků určitá - a nikoliv překvapivá - dominance hlavního města. Z kvalitativní perspektivy se pak ukázalo, že navzdory pomérně diferencovanému charakteru krajských měst je skladba př́spěvků o nich poměrně nepestrá a témata bulvární vytlačují témata rozvojově orientovaná.
\end{abstract}

\section{Klíčová slova}

Krajská města, sdělovaci prostředky, televizní zpravodajství, mentální mapy

\section{Annotation}

Media contributions related to individual territories contribute to the formation of mental maps. TV coverage has both high degree of impact on the public as well as sufficient representativeness. The objective of our article consists in quantitative and qualitative analysis and interpretation of contributions related to regional capitals in the framework of national TV coverage. We evaluated not only the amount of news related to individual regional metropolises but their composition as well. Our analysis showed that from quantitative point of view we are entitled to talk about certain and not surprising dominance of the capital city of Prague. From qualitative perspective it turned out that in spite of rather differentiated character of regional capitals the composition of news about them is much less motley. Moreover, tabloid topics tend to subdue development-orientated themes.

Key words

Regional capitals, media, TV coverage, mental maps

JEL classification: $R 10, M 30, B 50$

\section{Úvodem}

Každé území se vyznačuje jak materiálními tak i nemateriálními charakteristikami. V jednotlivých teritoriích žije obyvatelstvo, které svými aktivitami formuje konkrétní hmotné struktury. Každé území je ovšem popsatelné také v rovině nemateriální. Jedná se o jeho duchovní složku, celkovou atmosféru, ale také pověst a postavení na mentální mapě (Sucháček, 2005, Ježek, 2010, Rumpel, Slach, Koutský, 2010). 
Mentálním mapám je přitom věnována stále větší pozornost. Tyto mapy z obecného hlediska odrážejí psychologické vnímání prostoru. Nejedná se tedy o zachycení reálného prostoru, ale o jeho reflexi ve vnímání jednotlivců. Mentální mapy přitom nejsou pouhým vyobrazením prostorových preferencí, ale také spoluurčovatelem budoucích prostorových aktivit. Nárůst důležitosti mentálních map je v souladu se zvyšujícím se významem tzv. měkkých lokalizačních faktorů.

Reference sdělovacích prostředků o jednotlivých územích ovlivňují čtenáře, posluchače či diváky krátkodobě, což je v souladu se současnou akcentací krátkodobých, „ad hoc“ řešení. Teprve časté opakování určitých témat může ovlivňovat dlouhodobější sklony, postoje či chování populace. Kromě sdělovacích prostředků, které ovlivňují jednotlivce především z krátkodobého hlediska, se na utváření mentálních map výrazně podílejí také vzdělávací instituce, rodinné prostředí či okolní prostředí, jejichž působení je obvykle dlouhodobé (Sucháček, 2005).

Image jednotlivých území by pritom měla být $\mathrm{v}$ souladu $\mathrm{s}$ jejich specifickou nabídkou a charakteristikami. Ve skutečnosti bývají image jednotlivých území od reality často dosti vzdáleny. Velmi významnou roli hrají v tomto kontextu právě sdělovací prostředky. Média již zdaleka nejsou pouhým pozorovatelem událostí, spíše se stala jednosměrným zprostředkovatelem informací směrem od elitních skupin $\mathrm{k}$ široké veřejnosti a jsou schopna ovlivňovat běh každodenních událostí. Nikoliv náhodou se v souvislosti s neustále sílícím vlivem sdělovacích prostředků hovoří o tzv. mediokracii.

Neustále stoupá množství informací, kterým je obyvatelstvo v každém okamžiku vystaveno. Média zprostředkovávají informace selektivně, zobrazují tedy pouze dílčí výseče značně komplexní reality. Obyvatelstvo je tak nejen informováno, ale zároveň je usměrňováno jeho chování a vnímání reality. Mnozí lidé, at' už uvědoměle či neuvědoměle, dokonce přijímají médii vnucené názory či preference. Děje se tak prostřednictvím akcentace (agenda setting) anebo ignorace (agenda cutting) určitých témat, způsobem interpretace jevů a událostí a také jejich explanací a hodnocením, což má kromě jiného fatální vliv také na výše zmíněnou otázku teritoriální image a potažmo tvorbu mentálních map.

Posláním sdělovacích prostředků by mělo být poskytovat objektivní, ověřené, vyvážené, přesné a nestranné informace o událostech $\mathrm{v}$ jednotlivých teritorí́ch. Současná média však fungují spíše jako spolutvůrci prostředí, ve kterém žijeme. Již zmíněné strategie agenda-setting či agenda-cutting jsou přitom v hojné míře využívány.

Není proto udivující, že tradiční aktéři teritoriálního rozvoje jako veřejnosprávní instituce či podnikatelské subjekty jsou nuceni média respektovat. Sdělovací prostředky jsou jedním z rozhodujících zdrojů informací pro výše uvedené aktéry. A naopak, tito aktéři se obracejí na obyvatelstvo převážně prostřednictvím sdělovacích prostředků. Sdělovací prostředky tak do jisté míry představují oboustranně působící informační filtr mezi řídícími, resp. vliv uplatňujícími a řízenými, resp. ovlivňovanými aktéry a prvky územního rozvoje. Tyto neustále sílící trendy pouze znásobují vliv médií, která již zdaleka nejsou pouhým zprostředkovatelem informací.

Z prostorového hlediska je působení sdělovacích prostředků zásadní pro formování obrazu regionu především za jeho hranicemi. S ohledem na organizaci sdělovacích prostředků a jejich postavení $\mathrm{k}$ území, které pokrývají a o němž referují, můžeme hovořit o médiích celostátních, regionálních a místních. V zásadě se jedná o jakousi řádovou diferenciaci těchto médí́.

Celostátní masmédia, kterým se $\mathrm{v}$ naší práci věnujeme, využívají kromě jiného také informace $\mathrm{z}$ jednotlivých regionů, ale referují o nich na celostátní úrovni. V tomto př́ípadě bývají regionální informace řazeny ke zprávám celostátního charakteru a informacím ze zahraničí. Je zř̌jmé, že vliv celostátních sdělovacích prostředků na obyvatelstvo bude podstatně intenzivnější, nežli tomu je v případě médií regionálních. Právě zprávy v celostátních sdělovacích prostř̌edcích, které mají lokální či regionální konotace, velmi významně spoluutvářejí územní image a $\mathrm{v}$ agregovaném pohledu i mentální mapy (Sucháček, 2010). 
Prostorové rozložení ústředí českých sdělovacích prostředků se vyznačuje monocentrickým charakterem a celostátní sdělovací prostředky jsou koncentrovány do hlavního města. Hrozí zde přitom nebezpečí, že vzhledem k omezenému času či prostoru mohou mít ústředí těchto celostátních médií tendenci posuzovat dění v regionech (zejména těch vzdálenějších) poněkud zkreslenou optikou.

\section{Cíl a metodický postup}

Předložený článek představuje při vědomí stávajících datových omezení pokus o zachycení vybraných aspekti̊ obrazu krajských měst ve sdělovacích prostředcích a to z kvalitativní a kvantitativní perspektivy. $\mathrm{S}$ ohledem na dostatečnou reprezentativnost bude $\mathrm{v}$ rámci sdělovacích prostředků pozornost zaměřena na celostátní televizní zpravodajství. Cílem článku tedy je kvantitativní a kvalitativní analýza a interpretace referencí o krajských městech a to v rámci celostátního vysílání zpravodajství veřejnoprávní České televize a komerční televize Nova. S ohledem na rozsah článku je především empirická část textu pojatá syntetickým způsobem.

Pro analytický rozbor mediální prezentace zkoumaného území budou využita data kontinuálního výzkumu obsahu médií společnosti Media Tenor a to se zaměřením na televizní zpravodajské relace. Agendě televizního zpravodajství přisuzujeme ze všech v současnosti dostupných médií nejvyšší stupeň dopadu na publikum. Sledovanost hlavní zpravodajské relace televize Nova (Televizní noviny) se v období 9/2009 - 9/2011 pohybovala v intervalu 1,6 - 2,8 mil. diváků, Události České televize a Zprávy televize Prima ve stejném období zase sledovalo 500 tis. - 1,1 mil. diváků (Sucháček, Herot, 2012).

Mnozí přisuzují televiznímu zpravodajství také dostatečnou reprezentativnost: „Z výzkumů agendasetting vyplývá, že tematická struktura mediálních obsahů např́č médii se př́liš neliší. ... Stručně řečeno, tematická agenda zpravodajských médií se do velké míry překrývá. $Z$ tohoto důvodu není tak podstatné, zdali jsou předmětem naší analýzy tištěná či audiovizuální média. Na základě výsledků několika studií (českých i zahraničních) zpravodajských médií lze tvrdit, že agenda televizních stanic do velké míry reprezentuje také agendu tištěných a rozhlasových zpravodajských médií." (Nečas, 2009).

Stat' je zaměřena na kvantitativní a kvalitativní analýzu a interpretaci referencí o krajských městech v České republice a to $\mathrm{v}$ rámci celostátního vysílání zpravodajství České televize a televize Nova. Kvantitativní analýza a interpretace přitom bude zaměřena na počet př́spěvků $\mathrm{z}$ jednotlivých regionů vztažený k počtu obyvatel v tomto území žijící.

Kvalitativní analýza a interpretace se zase opírá o obsahovou skladbu př́íspěvků celostátního vysílání o jednotlivých regionech. Sledovanými zpravodajskými relacemi v rámci tohoto výzkumu jsou Události České televize, Události, komentáre České televize a Televizní noviny televize Nova.

Časové řady vztažené $\mathrm{k}$ tematické skladbě celostátních televizních př́spěvků o jednotlivých krajských městech budou realizovány za léta 2004-2010. Tyto časové řady nejsou príliš dlouhé a to především z důvodu relativní novosti celé tématiky. Na straně druhé již tyto časové řady umožňují získat alespoň základní přehled o vývojových tendencích v oblasti teritoriálních mediálních referencí o zkoumaných krajských městech.

\section{Výsledky}

\section{Kvantitativní aspekty obrazu krajských měst v celostátním televizním zpravodajství}

Jak již bylo naznačeno $\mathrm{v}$ předchozí subkapitole, počet obyvatel $\mathrm{v}$ daném území představuje vždy velmi důležitý faktor pro zachycení a vysvětlení prostorového sociálně-ekonomického vývoje. Různé aktivity se vždy váží na obyvatelstvo prítomné v daném území. Stejně tak by bez prítomnosti obyvatelstva, onoho primárního vývojového hybatele, nemohly $\mathrm{v}$ daných územích existovat ani 
hospodářské, sociální, kulturní, institucionální a jiné subsystémy. Interakce a procesy, které v území probíhají, by pak měly být alespoň přibližně reflektovány ve sdělovacích prostředcích, kdy by podíly obyvatelstva měly alespoň přibližně korespondovat s podíly referencí o daném území ve sdělovacích prostředcích.

Obrázek 1 nám ukazuje procentuální podíl zpráv o jednotlivých krajských městech v rámci celostátního vysílání pořadů Události České televize, Události, komentáře České televize a Televizní noviny televize Nova $\mathrm{z}$ celkového počtu zpráv o těchto městech ve zmíněných pořadech a procentuální podíl počtu obyvatel jednotlivých krajských měst na celkovém počtu obyvatel těchto krajských metropolí.

S ohledem na prostorový vzorec lokalizace celostátních sdělovacích prostředků v České republice nejsou výsledky této kvantitativní analýzy př́lišným překvapením. Viditelná je dominance Prahy, přičemž nutno upozornit, že pokud by se do analýzy zahrnuly územně vztažené př́spěvky o jiných, nežli výsostně městských tématech, jako například zahraniční politika, byl by náskok hlavního města ještě patrnější.

Obr. 1: Podíl mediálních př́spěvků krajských měst na celkovém počtu příspěvků o těchto městech a podíl obyvatelstva krajských měst na celkovém počtu obyvatel krajských měst

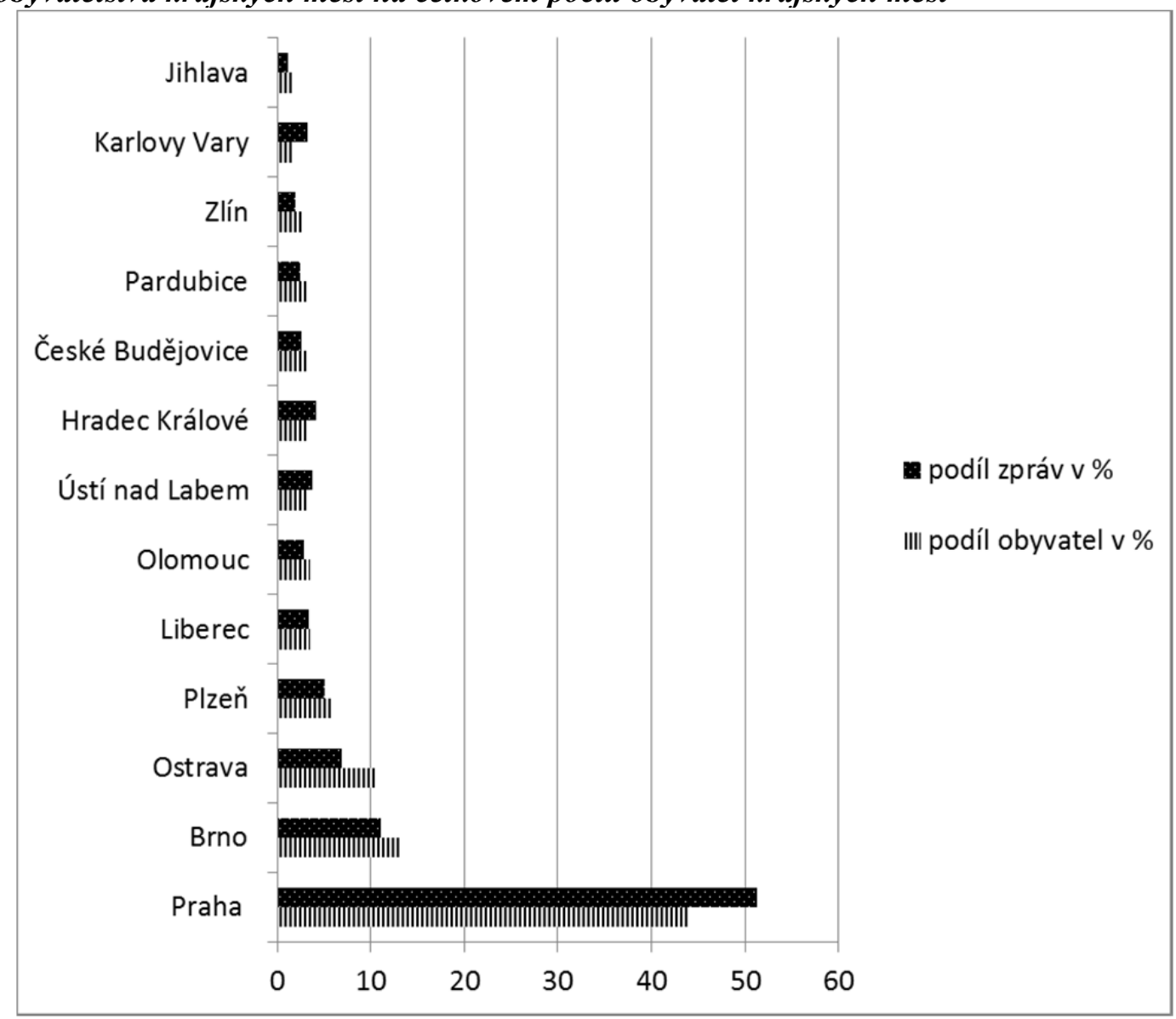

Zdroj: Interní materiály Media Tenor a výpočty autora

Znatelně nižší podíl př́spěvků ve sdělovacích prostředcích, nežli je jeho populační váha, pak má Brno a ještě více je tato situace patrná u Ostravy. Za povšimnutí přitom stojí, že jsou v obou městech lokalizována studia České televize, která prrispívají také do námi zkoumaných celostátních zpravodajských pořadů. Zatímco u Brna se může jevit podproporcionální podíl mediálních příspěvků jako poměrně překvapivý, u Ostravy se v zásadě jedná o mediální reflexi teze, že se prakticky po celou historii nacházelo celospolečenské uznání a administrativně-politické postavení tohoto města v kvalitativním zpoždění za jeho populačním a hospodářským významem (Sucháček, 2010). 
U ostatních krajských měst podíl jejich obyvatel přibližně koresponduje s podílem př́íspěvků ve sdělovacích prostředcích, což je zapříčiněno mimo jiné jejich nižšími populačními váhami. S ohledem na počet obyvatel je však o poznání vyšší mediální pozornost věnovaná například Karlovým Varům anebo Hradci Králové. Podproprocionání pozornost sdělovacích prostředkủ je naopak věnována krajským městům ve východní části země. Velmi málo pozornosti bylo pak věnováno metropoli kraje Vysočina Jihlavě.

\section{Kvalitativní aspekty obrazu krajských měst v celostátním televizním zpravodajství}

Předchozí text nám poskytl základní vhled do problematiky prostorově diferencovaných př́spěvků v celostátním televizním zpravodajství. Nutno přitom upozornit na fakt, že počet příspěvků o jednotlivých městech nám nic neř́ká o tom, $v$ jakém duchu se o nich hovoří. $Z$ tohoto důvodu je užitečné posuzovat také tematickou skladbu zpráv o jednotlivých územích a doplnit tak předchozí kvantitativní pohled na problém také perspektivou kvalitativní. V syntetické podobě nám kvalitativní aspekty obrazu krajských měst v celostátním televizním zpravodajství ukazuje tabulka 1.

Tab. 1: Krajská města podle četnosti tematických př̌́spěvků v celostátním televizním zpravodajství

\begin{tabular}{|c|c|c|c|c|c|}
\hline \multirow{2}{*}{$\begin{array}{l}\text { Města } \\
\text { seřazená } \\
\text { podle } \\
\text { populační } \\
\text { velikosti }\end{array}$} & \multicolumn{5}{|c|}{ Pět nejfrekventovanějších témat a jejich četnost } \\
\hline & 1 & 2 & 3 & 4 & 5 \\
\hline Praha & Bezpečnost 3450 & $\begin{array}{l}\text { Umění, kultura } \\
1803\end{array}$ & Společnost 1430 & Nehody 1142 & Doprava 699 \\
\hline Brno & Bezpečnost 815 & Nehody 263 & Společnost 225 & Justice 216 & $\begin{array}{l}\text { Zdravotnictví } \\
187\end{array}$ \\
\hline Ostrava & Bezpečnost 536 & Nehody 259 & Justice 121 & $\begin{array}{l}\text { Zdravotnictví } \\
103\end{array}$ & $\begin{array}{l}\text { Společnost } \\
102\end{array}$ \\
\hline Plzeň & Bezpečnost 399 & Školství, věda 123 & Justice 118 & Nehody 114 & $\begin{array}{l}\text { Společnost } \\
106\end{array}$ \\
\hline Liberec & Bezpečnost 201 & Nehody 144 & Sport 78 & $\begin{array}{l}\text { Životní prostředí } \\
60\end{array}$ & $\begin{array}{l}\text { Společnost } \\
48\end{array}$ \\
\hline Olomouc & Bezpečnost 205 & Nehody 132 & $\begin{array}{l}\text { Životní prostředí } \\
58\end{array}$ & Společnost 53 & Justice 52 \\
\hline $\begin{array}{ll}\text { Ústí } & \text { nad } \\
\text { Labem } & \\
\end{array}$ & Bezpečnost 318 & Nehody 112 & Justice 60 & Zdravotnictví 58 & $\begin{array}{l}\text { Životní } \\
\text { prostrededí } 58\end{array}$ \\
\hline $\begin{array}{l}\text { Hradec } \\
\text { Králové }\end{array}$ & Bezpečnost 266 & Nehody 143 & Justice 96 & Společnost 66 & $\begin{array}{l}\text { Umění, } \\
\text { kultura } 60\end{array}$ \\
\hline $\begin{array}{l}\text { České } \\
\text { Budějovice }\end{array}$ & Bezpečnost 165 & Nehody 101 & Zdravotnictví 62 & Společnost 45 & $\begin{array}{l}\text { Umění, } \\
\text { kultura } 37\end{array}$ \\
\hline Pardubice & Bezpečnost 109 & Nehody 75 & Společnost 56 & Zdravotnictví 52 & Sport 50 \\
\hline Zlín & Bezpečnost 93 & Společnost 75 & Nehody 69 & Zdravotnictví 38 & $\begin{array}{l}\text { Umění, } \\
\text { kultura } 35\end{array}$ \\
\hline $\begin{array}{l}\text { Karlovy } \\
\text { Vary }\end{array}$ & $\begin{array}{l}\text { Umění, kultura } \\
238\end{array}$ & Bezpečnost 135 & Zdravotnictví 66 & Společnost 52 & Nehody 52 \\
\hline Jihlava & Bezpečnost 64 & $\begin{array}{l}\text { Životní prostředí } \\
27\end{array}$ & Nehody 25 & $\begin{array}{l}\text { Umění, kultura } \\
20\end{array}$ & $\begin{array}{l}\text { Stranická } \\
\text { oblast } 20\end{array}$ \\
\hline
\end{tabular}

Zdroj: Interní materiály Media Tenor a výpočty autora

Obraz hlavního města se v celostátním zpravodajství částečně překrývá s ostatními krajskými městy. Přesto nese celostátní zpravodajství věnované Praze jeden unikátní rys a tím je silné zastoupení zpráv věnovaných umění a kultuře. Žádné jiné ze sledovaných měst se nemůže pochlubit $\mathrm{z}$ absolutního pohledu tak velkým počtem zpráv z umělecké a kulturní sféry.

Vezmeme-li v úvahu odlišný charakter a problémy Brna a Ostravy, je podobnost témat na prvních místech až překvapující. Témata spjatá s životním prostředím jsou v Ostravě akcentována až v posledních letech, proto v celkovém hodnocení obsadila sedmé místo. Naopak u Ústí nad Labem se 
téma životního prostředí dostalo mezi pět nejvýznamnějších, nicméně celková skladba zpráv o městě opět ukazuje spíše na témata bulvární, než rozvojově orientovaná.

Silné postaven tématu věda a školství u Plzně se zase váže na aféru spojenou s ne právě průhledným udělováním diplomů na Západočeské univerzitě. Další témata u západočeské metropole pak v zásadě korespondují s ostatními městy.

Profil Hradce Králové nese také podobnost s ostatními krajskými městy. Za povšimnutí stojí, že se mezi pět nejfrekventovanějších témat dostalo umění a kultura. Také Olomouc působí až na oblast životního prostředí spíše nenápadně.

Zajímavá je situace $\mathrm{v}$ případě Liberce, kde se dostalo na poměrně vysokou přičcku téma sportu. $\mathrm{V}$ roce 2009 se totiž v tomto městě konalo Mistrovství světa v klasickém lyžování, což byla jedna z největších sportovních akcí v historii České republiky. Tato akce se nakonec v mnoha ohledech ukázala jako poměrně kontroverzní a tedy i mediálně atraktivní.

Zatímco České Budějovice, Zlín a Pardubice výrazněji nevybočují z obsahové skladby celostátních médií o krajských městech, Karlovy Vary výrazněji těží z pravidelně pořádaného filmového festivalu. Jedná se o jediné ze sledovaných měst, kde první místo nebylo obsazeno tématem bezpečnost. Kromě toho je Karlovým Varům s ohledem na počet obyvatel věnována také nadproporcionální pozornost. Specifické pak je populačně nejmenši krajské město Jihlava. Ve sledovaném období se k němu vztahoval výrazně menší počet příspěvků, nežli k městům ostatním.

\section{Závěrem}

Sdělovací prostředky jsou důležitou entitou, která se podílí na spoluutváření mentálních map. Jak bylo $\mathrm{v}$ článku ukázáno, z kvantitativního hlediska se u počtu př́spěvků projevuje určitá a do jisté míry očekávaná dominance hlavního města. Znatelně nižší podíl příspěvků ve sdělovacích prostředcích, nežli je jeho populační váha, pak má Brno, což lze hodnotit jako skutečnost poměrně překvapivou. Citelně podproporcionální podíl př́spěvků lze ve vazbě na počet obyvatel pozorovat také u Ostravy. Zatímco u ostatních krajských měst počet příspěvků přibližně reflektuje počet jejich obyvatel, Karlovým Varům a Hradci Králové je věnována pozornost nadproporcionální.

Z kvalitativního hlediska, které vhodně doplňuje a rozvádí perspektivu kvantitativní, se pak ukázalo, že navzdory poměrně diferencovanému charakteru krajských měst je skladba př́ispěvků o nich dosti homogenní. Mediální obrázek krajských měst se vyznačuje nediferencovaným, až amorfním charakterem; vždyt' se mezi pěti nejfrekventovanějšími tématy u sledovaných třinácti krajských měst objevilo v souhrnu pouze jedenáct témat. Témata bulvární, jakými jsou bezpečnost, nehody či justice pak často zřetelně dominují nad tématy pro města př́ínosnějšími. Mezinárodním událostem, Evropské unii a celé řadě dalších rozvojově orientovaných sfér je věnována pozornost vskutku minimální. Za povšimnutí také stojí, jak silně byly výsledky některých měst ovlivněny jednou či několika málo událostmi.

\section{Literatura}

[1] JEŽEK, J. Aplikace městského marketingu v tranzitivních ekonomikách. E+M Ekonomie a management, 2010, roč. 13, č.4, s.123-134, ISSN 1212-3609.

[2] NEČAS, V. Mediální kontext české zahraniční politiky. In Kořan, M. et al. Česká zahraniční politika v roce 2008, Praha: Ústav mezinárodních vztahů, 2009. s. 41-48, ISBN 978-80-8650678-4.

[3] RUMPEL, P., SLACH, O., KOUTSKÝ, J. Creative Industries in Spatial Perspective in the Old Industrial Moravian-Silesian Region. E+M Ekonomie a Management, 2010, roč. 13, č.4, s. 30-46, ISSN 1212-3609. 
[4] SUCHÁČEK, J., HEROT P. Meditorial Development: The Case of Czech Republic. European Journal of Social Sciences, 2012, Vol. 34, No 3, pp. 461-471, ISSN 1450-2267.

[5] SUCHÁČEK, J. Na cestě k nové identitě. Ostrava, Katovice, Karviná po roce 1989. Ostrava: VŠB-Technická univerzita, 2010. ISBN 978-80-248-2212-9.

[6] SUCHÁČEK, J. Restrukturalizace tradičnich průmyslových regionů v tranzitivnich ekonomikách. Ostrava: VŠB -Technická univerzita, 2005. ISBN 80-248-0865-X.

Př́spěvek byl zpracován v rámci grantu SP2013/126 ,Mediální obraz regionů v České republice: kvantitativní a kvalitativní aspekty a souvislosti“ na Ekonomické fakultě V̌̆B-TU v Ostravě. 